\title{
Flow separation and diurnal variability in the hydrology of Conness Glacier, Sierra Nevada, California, U.S.A.
}

\author{
SCOTT A. LeCCE \\ Department of Geography, University of Wisconsin, Madison, Wisconsin 53706, U.S.A.
}

\begin{abstract}
A mass-balance approach using hourly discharge and electrical conductivity values measured over a $10 \mathrm{~d}$ period during the ablation season was used to separate englacial and subglacial components of the total meltwater discharge from a small alpine glacier in the Sierra Nevada, California, U.S.A. Symmetrical diurnal hydrographs indicate that little delay occurred as water was tranferred through the drainage system. Electrical conductivity (which varied inversely with proglacial discharge) increased abruptly at each daily conductivity maximum, and cross-correlation analysis indicated that subglacial discharge peaked on the rising limb of the englacial hydrograph (about $2 \mathrm{~h}$ prior to the englacial peak). This suggests that a translatory flow process operates in which increased water pressure in the englacial system on the rising limb of the diurnal-discharge cycle forced subglacial water from beneath the glacier in advance of short residence-time meltwater. Net radiation dominated the energy balance at the glacier surface, explaining $86 \%$ of the variance in proglacial discharge, which was dominated by the englacial flow component.
\end{abstract}

\section{INTRODUCTION}

Knowledge of the characteristics of drainage systems beneath glaciers is important in order to understand glacier movement (Collins, 1979b); however, little is known about how these internal drainage networks function, and more specifically, the nature of the relationship between englacial and subglacial drainage systems. The few studies that have attempted to quantify the interaction between englacial and subglacial discharge have been accomplished on relatively large alpine glaciers, primarily in the Swiss and Austrian Alps (Collins, 1978, 1979b; Oerter and others, 1980; Gurnell and Fenn, 1984). Although it is generally recognized that glacial meltwater flows through both englacial and subglacial pathways (Röthlisberger, 1972; Shreve, 1972; Collins, 1979b), previous research has suggested that the relative proportion and timing of these flow components may vary significantly from glacier to glacier (Fenn, 1987, p. 409), and may be related to glacier size (Gurnell and Fenn, 1984, p. 115). This study examines the subglacial and englacial hydrology of a middle-latitude cirque glacier in an alpine environment. The objectives were (1) to examine diurnal variations of discharge and electrical conductivity, (2) to separate englacial and subglacial components of the total meltwater discharge in order to evaluate the characteristics of the flow-routing system, and (3) to assess the relationship between proglacial discharge and energy conditions at the glacier surface.

\section{STUDY AREA}

Conness Glacier $\left(<0.5 \mathrm{~km}^{2}\right)$ is located at an elevation of about $3400 \mathrm{~m}$ in a small northeast-facing cirque on the eastern side of the Sierra Nevada crest in California, U.S.A. (Figs 1 and 2). Active glaciers in the Sierra Nevada are small (the largest is Palisades Glacier $\left.\left(\approx 1.2 \mathrm{~km}^{2}\right)\right)$ and entirely restricted to high-altitude northeast-facing cirques where favorable microclimatological conditions have allowed their continued existence during Holocene warming. Proglacial discharge from Conness Glacier flows into Lee Vining Creek and eventually into the closed basin occupied by Mono Lake. Lee Vining Creek is one of five streams feeding Mono Lake from which the city of Los Angeles currently appropriates water.

This temperate glacier rests in a deep basin surrounded by high cirque headwalls and morainal ridges $(40-60 \mathrm{~m}$ high at their lower end). The end moraine forms an effective barrier to katabatic flow and the resulting cold-air ponding may be an important factor slowing the ablation rate on the lower end of the glacier (Chambers, 1990). The catchment that contributes runoff to the proglacial stream is almost completely icecovered and underlain entirely by the late Cretaceous Cathedral Peak granodiorite (Bateman and others, 1983). Steep bedrock slopes and the lack of soil in the surrounding alpine environment suggest a negligible groundwater contribution to proglacial discharge.

A medial moraine exposed at the surface divides the 


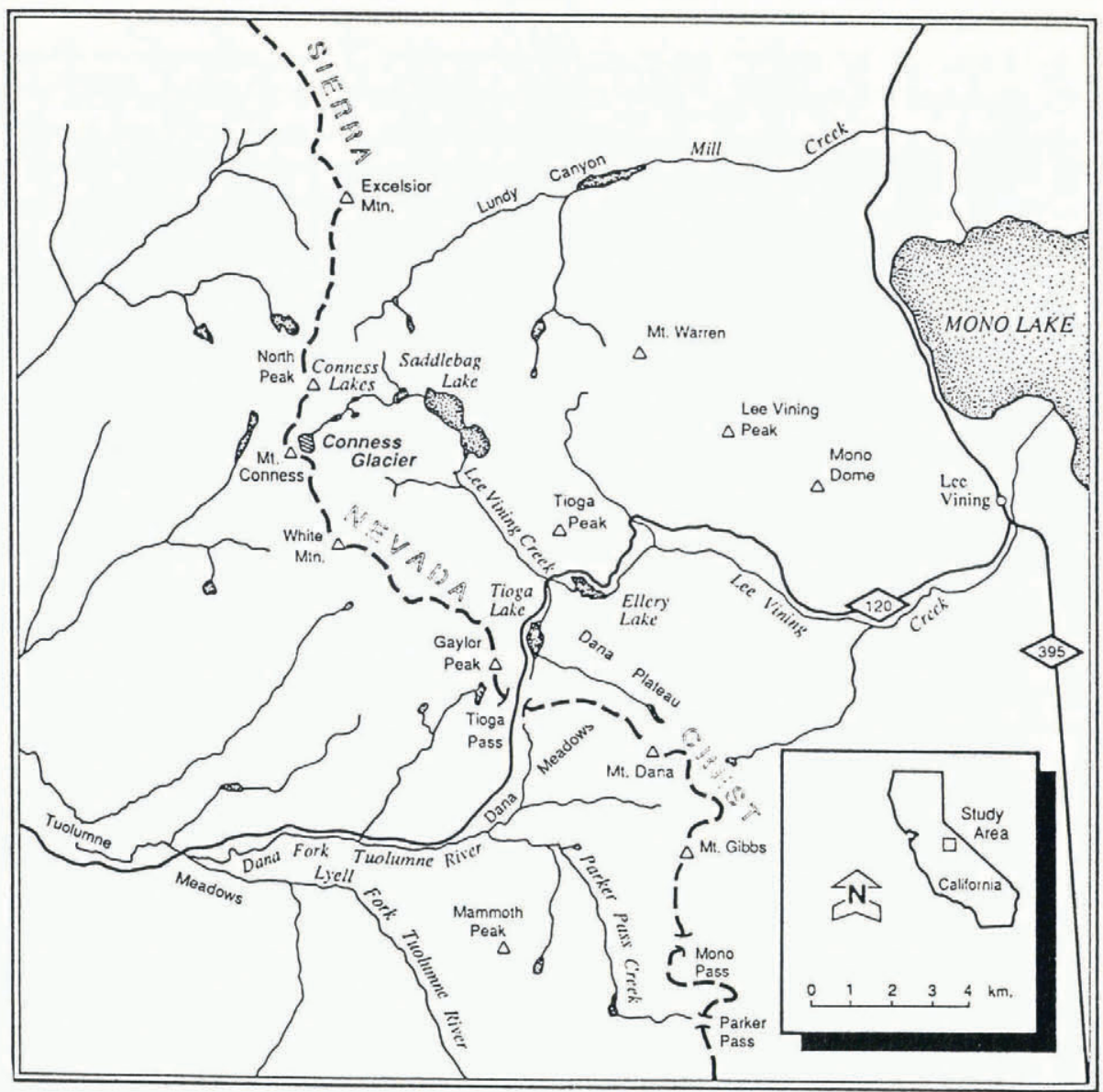

Fig. 1. Location of Conness Glacier in the Sierra Nevada, California, U.S.A.

glacier into two main lobes. Meltwater from the western lobe percolates through and beyond the end moraine and therefore could not be monitored. However, meltwater from the eastern lobe flows in a proglacial stream which was monitored about $50 \mathrm{~m}$ downstream from the ice margin before percolating through the end moraine. Field data were collected during the $10 \mathrm{~d}$ period 13-23 August 1989 at the peak of the ablation season while snow on the glacier surface was melting to expose bare ice.

\section{METHODS}

\section{Glacial hydrology}

Chemical characteristics of stream water have often been used to identify surface-water sources and pathways through which water is routed to the stream channel (Pinder and Jones, 1969; Brown, 1986; Hooper and Shoemaker, 1986; Caine, 1989). Collins (1978, 1979b) and Gurnell and Fenn (1984) have used the solute concentration in meltwater run-off to separate flow into two pathways through the glacial hydrologic system. Englacial flow pases through sediment-free, ice-walled conduits or in supraglacial channels where minimal chemical enrichment occurs. Subglacial flow acquires solutes as it moves (at slower overall rates) in contact with bedrock, sediment and sediment-laden basal ice. The term englacial does not necessarily define conduit location. Englacial conduits may be located at the bed

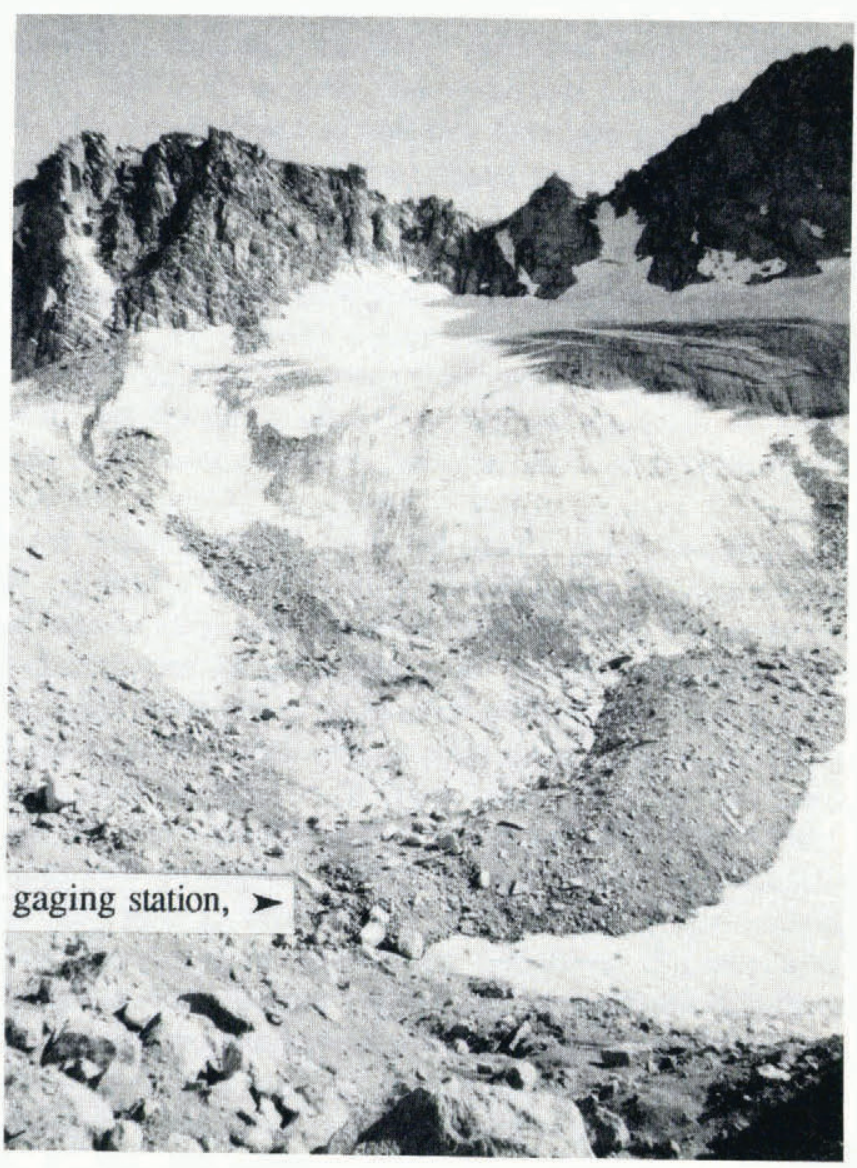

Fig. 2. A view of Conness Glacier looking south. 
without chemical enrichment due to the passage of large volumes of water at high rates of flow that lack sufficient contact with ion-rich materials (Collins, 1979b). Subglacial conduits, however, are located exclusively at the glacier bed.

Continuity of flow implies:

$$
Q_{\mathrm{t}}=Q_{\mathrm{s}}+Q_{\mathrm{e}}
$$

where $Q$ is discharge $\left(1 \mathrm{~s}^{-1}\right)$ and the subscripts, $\mathrm{t}$, e and $\mathrm{s}$ represent total, englacial and subglacial flow components, respectively. The solute concentration of the total discharge at the proglacial stream $\left(C_{\mathrm{t}}\right)$ is the weighted mean of englacial- and subglacial-flow contributions:

$$
C_{\mathrm{t}}=\left(C_{\mathrm{e}} Q_{\mathrm{e}}+C_{\mathrm{s}} Q_{\mathrm{s}}\right) / Q_{\mathrm{t}}
$$

where $C$ is solute concentration approximated by electrical conductivity $\left(\mu \mathrm{S} \mathrm{cm}^{-1}\right)$. Solving for $Q_{\mathrm{s}}$ allows the subglacial-flow component to be estimated (Collins, 1979b):

$$
\left.Q_{\mathrm{s}}=\left[\left(C_{\mathrm{t}}-C_{\mathrm{e}}\right) / C_{\mathrm{s}}-C_{\mathrm{e}}\right)\right] Q_{\mathrm{t}} .
$$

Proglacial discharge $\left(Q_{\mathrm{t}}\right)$ and electrical conductivity $\left(C_{\mathrm{t}}\right)$ were monitored at a stable channel cross-section where pygmy meter velocity measurements were used to establish a stage-discharge rating curve (sample size $=$ $\left.29 ; R^{2}=0.94\right)$. Stage was recorded hourly from 0600 to $2200 \mathrm{~h}$, and at 2400 and $0300 \mathrm{~h}$ during the night. However, discharge measurements during the night $(2400-0800 \mathrm{~h})$ were omitted because freezing temperatures produced ice at the gaging station, resulting in inaccurate stage readings. This did not pose a serious problem because discharge had decreased to low rates before freezing occurred and the ice broke up quickly in the morning as stage began to rise. Visual observations suggested that flow had declined to a trickle (probably less than $51 \mathrm{~s} \mathrm{~s}^{-1}$ ) by the early morning hours.

Electrical conductivity provides an adequate proxy of total dissolved solids concentration (Fenn, 1987) and was determined from 11 samples with a portable Cole-Parmer 1481-55 conductivity meter. Previous researchers have suggested that conductivity values should not be corrected to a standard temperature (Collins, 1979b; Gurnell and Fenn, 1984); however, the instrument used automatically standardizes conductivity values to a temperature of $25^{\circ} \mathrm{C}$ (accurate to within $\pm 0.1 \mu \mathrm{S} \mathrm{cm}^{-1}$ ). The potential impact of using temperature-corrected values was examined by estimating uncorrected conductivity values from meltwater temperature (which ranged from $0^{\circ}$ to $5^{\circ} \mathrm{C}$ ) and using a correction factor of $1.92 \%{ }^{\circ} \mathrm{C}^{-1}$. This suggested that temporal trends in the uncorrected values are about $30 \%$ lower (on average). Substituting uncorrected values for $C_{\mathrm{s}}$ and $C_{\mathrm{e}}$ in Equation (3) produced no change in subglacial and englacial discharges, thus using temperature-corrected conductivity values does not influence the results.

Separation of the total discharge into its englacial and subglacial flow components using Equation (3) relies upon accurate estimation of $C_{\mathrm{e}}$ and $C_{\mathrm{s}}$ (Collins, 1979b; Fenn, 1987, p. 408). Following Collins (1979b), estimates were obtained for $C_{\mathrm{e}}$ by using the average electrical conductivity sampled from meltwater on the glacier surface, and for $C_{\mathrm{s}}$ by using the maximum conductivity recorded following a snowfall event on 20 August (when dilution by englacial flow was minimal). The estimates used in this study were $C_{\mathrm{e}}=1.4 \mu \mathrm{S} \mathrm{cm}^{-1}$ (std dev. = $0.2 \mu \mathrm{S} \mathrm{cm}^{-1}$ ) and $C_{\mathrm{s}}=9.0 \mu \mathrm{S} \mathrm{cm}^{-1} . C_{\mathrm{s}}$ should be regarded as a minimum estimate of the true subglacial conductivity, since it is possible that some dilution by englacial flow occurred at the time of measurement. Estimates of $C_{\mathrm{e}}$ and $C_{8}$ can be subject to considerable error (Collins, 1979b; Fenn, 1987, p. 408-09); however, Gurnell and Fenn (1984) demonstrated that, while such errors can produce substantial variations in the magnitude of $Q_{\mathrm{e}}$ and $Q_{\mathrm{s}}$, the temporal pattern of each discharge component remains relatively constant. Consequently, the values chosen for $C_{\mathrm{e}}$ and $C_{\mathrm{s}}$ should not influence the results reported in this paper, which are temporal in nature.

The contribution of solute-rich water from nonsubglacial sources (i.e. permafrost or marginal streams) is a potential source of error in this analysis. However, solute-rich meltwater from permafrost surrounding the glacier was regarded as minimal because there was no channelized water flowing into the glacier, and any unconcentrated flow trickling towards the glacier would have frozen during the night. Solute-rich flow cannot be explained by flow along the glacier margins because all marginal flow stopped when ablation ceased each night. Several low conductivity values $\left(1.5-2.2 \mu \mathrm{S} \mathrm{cm}^{-1}\right)$ recorded during the day in marginal streams suggest that their source was primarily from surface melting.

\section{Energy balance}

The energy available for melting ice and snow at the glacier surface is

$$
Q_{\mathrm{M}}=Q_{\mathrm{NR}}+Q_{\mathrm{H}}+Q_{\mathrm{E}}+Q_{\mathrm{P}}+Q_{\mathrm{G}}
$$

where $Q_{\mathrm{M}}$ is the energy available for melting, $Q_{\mathrm{NR}}$ is net all-wave radiation, $Q_{\mathrm{H}}$ is the sensible-heat flux, $Q_{\mathrm{E}}$ is the latent-heat flux, $Q_{\mathrm{P}}$ is the heat provided by precipitation and $Q_{\mathrm{G}}$ is the conductive-heat flux in the snow or ice (all units in $\mathrm{kJ} \mathrm{m}^{-2} \mathrm{~h}^{-1}$ ) (Wendler and Weller, 1974; Röthlisberger and Lang, 1987). The energy-balance equation was simplified to include only $Q_{\mathrm{NR}}, Q_{\mathrm{H}}$ and $Q_{\mathrm{E}}$, because it is reasonable to assume that the conductive heat flux in the ice was negligible (Marcus and others, 1985) and there wus no rainfall during the study period.

The meteorological station was located on the lower third of the glacier at a site representative of surface conditions. $Q_{\mathrm{NR}}$ was measured directly, while $Q_{\mathrm{H}}$ and $Q_{\mathrm{E}}$ were calculated by the bulk-transfer approach described by Male and Gray (1981, p. 390-91). Values assumed for the bulk-transfer coefficients were $D_{\mathrm{H}}=1.68$ and $D_{\mathrm{E}}=$ 8.0 (see table 9.3 in Male and Gray (1981, p. 392)). These values are only first approximations (Male and Gray, 1981, p. 391); however, errors were considered minimal due to the small sensible- and latent-heat fluxes measured during the study period. All raw data were recorded on a data logger and compiled into hourly values. 


\section{RESULTS AND DISCUSSION}

\section{Diurnal variations of discharge and electrical conductivity}

The discharge hydrograph and temporal variations in electrical conductivity for the $10 \mathrm{~d}$ period of record are shown in Figure 3. Discharge hydrographs demonstrate diurnal cycles distinctive of ablation-controled glacial run-off. Peak discharge typically occurred between 1400 and $1600 \mathrm{~h}$, except on 20 August when the peak discharge reached only $261 \mathrm{~s}^{-1}$ at $1100 \mathrm{~h}$. On this day, the morning sky was overcast and at about $1300 \mathrm{~h}$ light snow began to fall. Diurnal hydrographs are fairly symmetrical, suggesting that there was little delay in flow as meltwater was quickly routed through the drainage system. Small glaciers are not likely to have the significant delays in flow that would produce asymmetrical diurnal hydrographs reported for larger glaciers (e.g. Collins, 1979b).

Diurnal fluctuations in electrical conductivity varied inversely with discharge (Fig. 3), as observed in other proglacial streams (Collins, 1979b; Gurnell and Fenn, 1985; Rainwater and Guy, 1961). Minimum daily conductivity values (occurring between about 1300 and $1800 \mathrm{~h}$ ) are much smaller than previously reported values (see Fenn, 1987, p. 408). This is probably due to the resistance of the granitic bedrock to rapid chemical breakdown and the small size of the glacier, where limited contact occurs with ionic source materials beneath the glacier and water-travel distances are short. Nevertheless, the variability in conductivity shown in Figure 3 suggests that it is possible to separate flow into its englacial and subglacial components even where conductivity values are relatively low.

Diurnal conductivity cycles are asymmetrical, with steep falling limbs (Fig. 3). Following peak discharge, the conductivity increased slowly as the proportion of solutefree englacial water declined, with peak conductivity usually occurring at $0900 \mathrm{~h}$. An abrupt increase in conductivity occurs at each conductivity maximum, suggesting that a translatory-flow effect exists (Gurnell and Fenn, 1984), in which the sudden input of meltwater associated with the onset of ablation on the glacier surface flushes solute-rich subglacial water at a time when proglacial flow is minimal. As surface melting continues,

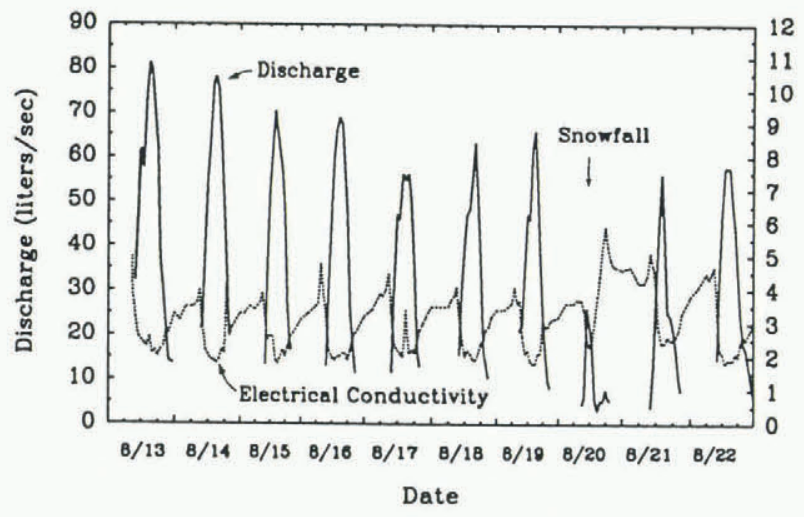

Fig. 3. Discharge (solid line) and electrical conductivity (dotted line) time-series during the study period 13-22 August 1989. englacial flow dilutes solute-rich subglacial flow, producing a rapid decline in conductivity.

The conductivity time-series occasionally demonstrates anomalously high values that deviate from the otherwise smooth trends in Figure 3. In such cases, an additional reading was taken immediately and in every case conductivity had dropped back down to normal levels. The possibility of instrument or operator error was eliminated by re-checking both the original sample and the follow-up sample. These anomalous conductivity readings are therefore interpolated as pulses of chemically enriched water periodically released from storage beneath the glacier. Due to limitations of discrete (hourly) sampling, it is impossible to know how frequently these pulses moved through the system unmonitored.

\section{Flow separation}

Using Equation (3), the total meltwater discharge was separated into its englacial and subglacial components (Fig. 4). The amount of water routed through the subglacial system was substantially less than that directed through the englacial system, which contributed most of the water $(\approx 75-95 \%)$ to the proglacial stream. The proportion of water routed subglacially through Conness Glacier $(\approx 5-25 \%)$ appears to have been considerably less than amounts reported by Collins (1979b, p. 356) for Findelengletscher $(40-60 \%)$ and Gornergletscher $(20-40 \%)$; however, it should be recognized that the absolute magnitude of the flow
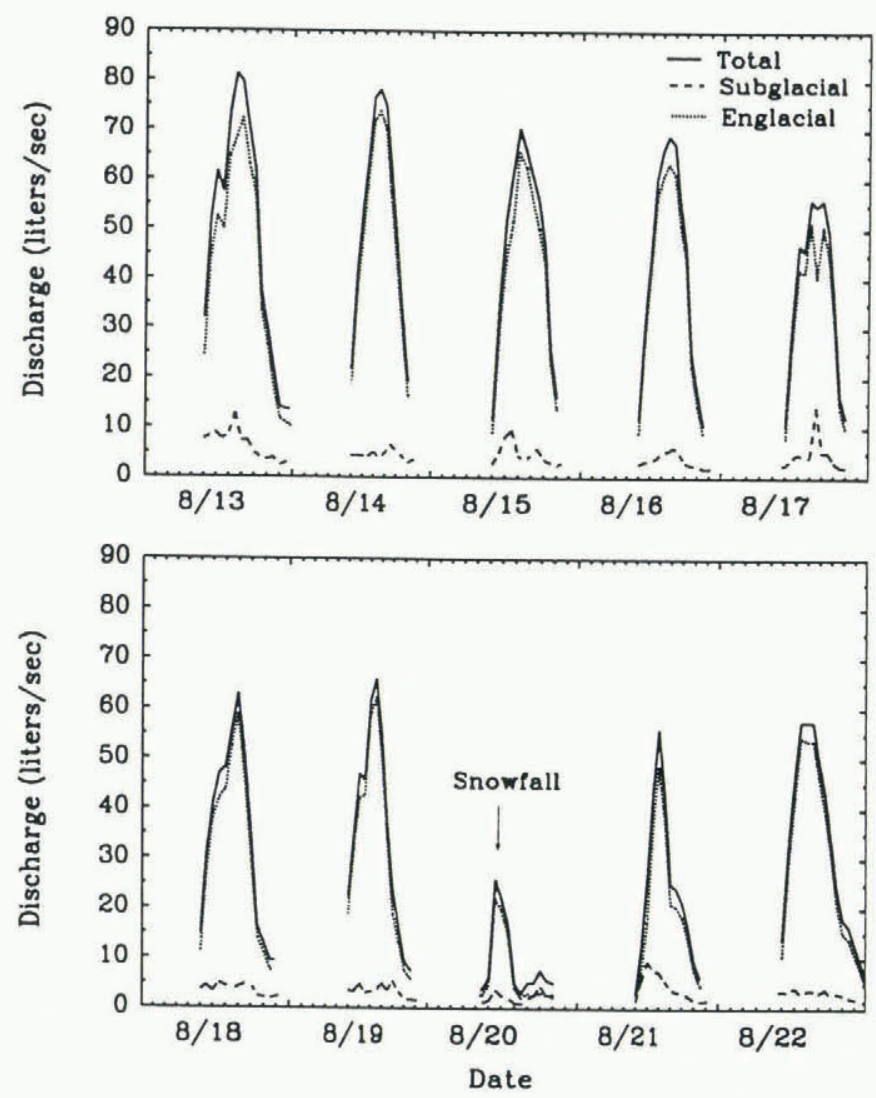

Fig. 4. Subglacial (dashed line), englacial (dotted line) and total discharge (solid line) time-series, 13-22 August 1989. 
components are sensitive to the estimates used for $C_{\mathrm{s}}$ and $C_{\mathrm{e}}$, and are therefore only approximate.

Most of the subglacial flow did not exit from beneath the glacier terminus. Instead, it emerged from within the lower third of the glacier and went into two main supraglacial channels. During peak proglacial discharge, conductivity in these two supraglacial streams was consistently higher than that in the proglacial stream, or in the other supraglacial channels, indicating its subglacial origin. During the night, when ablationderived englacial flow was minimal, these two supraglacial channels were the only significant sources of water to the proglacial stream.

Subglacial-discharge cycles in Figure 4 are symmetrical and appear to vary approximately in phase with the englacial cycles. However, cross-correlation analysis between the two time-series suggests that, on average, they are not perfectly in phase (Table 1). Instead, subglacial discharge peaked $2 \mathrm{~h}$ before the englacial peak, while englacial and proglacial peaks were nearly in phase.

Collins (1979b) has suggested that an in-phase response between $Q_{\mathrm{e}}$ and $Q_{\mathrm{s}}$ indicates that englacial and subglacial conduits are widely interconnected. His inphase model for Findelengletscher differs from that observed on Gornergletscher (Collins, 1979b), where subglacial discharge was out-of-phase with total discharge, and Tsidjiore Nouve Glacier (Gurnell and Fenn, 1984), where subglacial discharge peaked on the rising limb of the englacial cycle. Collins (1979b) interpreted his data from Gornergletscher as implying that diurnal water-pressure peaks forced subglacial water into storage in cavities, which was not released until water pressure declined. When water pressure was high in Conness Glacier, subglacial water was presumably not diverted into cavities or into storage in basal sediments, as this would have produced an out-of-phase response. This may also indicate an absence of thick basal sediments or large subglacial cavities to store water.
On Conness Glacier, the peaking of subglacial discharge on the rising limb of the englacial discharge cycle is similar to that described by Gurnell and Fenn (1984) on Tsidjiore Nouve Glacier, where peak $Q_{\mathbf{s}}$ preceded peak $Q_{\mathrm{e}}$ by $1-13 \mathrm{~h}$. They proposed a translatory flow effect with waters which were delayed in the basal-conduit system overnight being forced out to form a peak in subglacial discharge ahead of water queued in the englacial system (Fenn, 1987, p. 409). The abrupt daily peaks in the conductivity series (described earlier) further support this interpretation. Although much of the surface meltwater generated during the day on Conness Glacier was observed flowing in supraglacial channels, increased water pressure in the englacial system on the rising limb of the discharge cycle was apparently sufficient to force water from the subglacial system.

The lag observed between englacial and subglacial flow on Conness Glacier is probably closely related to its small size and the relative simplicity of its drainage system. Lags measured at the proglacial outlet on large glaciers that have contributing tributary glaciers may depend on how flow is routed from tributary glaciers that have differences in travel distances and source materials. As such, Conness Glacier is a useful example of the translatory-flow effect because it lacks some of the complexity likely to occur on larger glaciers.

\section{Energy balance}

The energy balance was dominated by the net radiation $\left(Q_{\mathrm{NR}}\right)$ component throughout the study period, accounting for (on average during the daylight hours) $98.4 \%$ of the energy available for surface melting $\left(Q_{\mathrm{M}}\right)$. Plotting proglacial discharge $\left(Q_{\mathrm{t}}\right)$ with $Q_{\mathrm{NR}}$ (Fig. 5) reveals that the two series correspond quite closely, with peak $Q_{\mathrm{t}}$ occurring an average of $1 \mathrm{~h}$ after the peak in $Q_{\mathrm{NR}}$ (Table 1). Incorporating this lag into a regression model shows that because internal-water storage and latent- and sensible-heat fluxes were minimal, $Q_{\mathrm{NR}-1}\left(Q_{\mathrm{NR}}\right.$ at time

Table 1. Time lags and cross-correlation coefficients

Input variable Output variable
Lag coefficient
Net radiation $\left(Q_{\mathrm{NR}}\right)$
Net radiation $\left(Q_{\mathrm{NR}}\right)$
Net radiation $\left(Q_{\mathrm{NR}}\right)$
Englacial discharge $\left(Q_{\mathrm{e}}\right)$
Proglacial discharge $\left(Q_{\mathrm{t}}\right.$
Proglacial discharge $\left(Q_{\mathrm{t}}\right.$

* Lags are in hours. Positive lags indicate that the input variable peaked before the peak for the output variable, while
negative lags indicate that the input variable peaked after the output variable. 

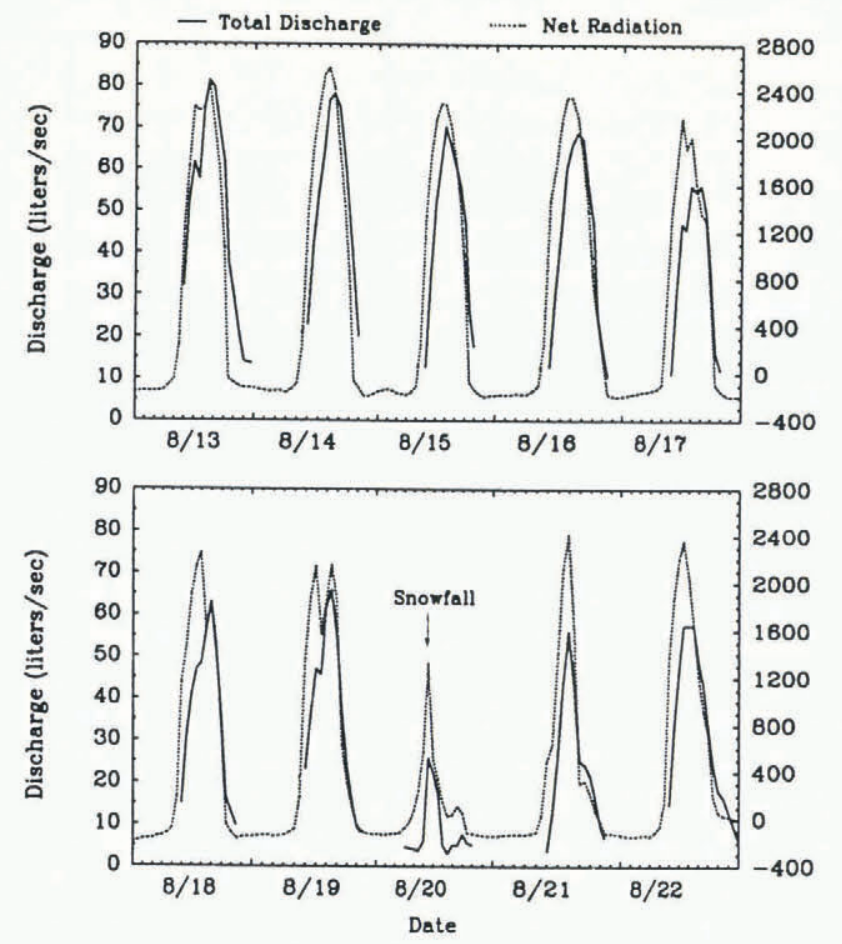

Fig. 5. Net radiation (dotted line) and total discharge (solid line), 13-22 August 1989.

$t-1$ ) is strongly correlated with proglacial discharge during the daylight hours, explaining $86 \%$ of the variance in $Q_{\mathrm{t}}$ (Table 2).

The strength of the relationships between net radiation and the different flow components are useful in examining further the routing of meltwater through the englacial and subglacial systems. The regression equations in Table 2 compare relationships between unlagged and lagged variables (as indicated in Table 1 by crosscorrelation). Lagging the variables improved the $R^{2}$ and reduced serial autocorrelation in the residuals. The weak relation between $Q_{\mathrm{NR}+1}$ and $Q_{\mathrm{s}}\left(R^{2}=0.07\right)$, compared to the relation between $Q_{\mathrm{NR}-1}$ and $Q_{\mathrm{e}}\left(R^{2}=0.70\right)$, suggests that while the subglacial system was probably integrated with the englacial system, much of the ablation-derived meltwater was transported englacially, or that the residence time of water routed subglacially was too short to acquire solutes. The strong relation between $Q_{\mathrm{NR}-1}$ and $Q_{\mathrm{e}}\left(R^{2}=0.70\right)$ demonstrates the close association between surface ablation and englacial flow, and the englacial dominance of proglacial discharge.

The snowfall event on 20 August, which produced an immediate decrease in both net radiation and total discharge, and the most abrupt increase in electrical conductivity, further illustrates the sensitivity of this small glacier to surface-energy conditions and its rapid hydrologic response. The decrease in net radiation can be attributed to a reduction in incoming short wave due to cloud cover, and an increase in the proportion of short wave reflected due to the greater albedo of the snow. Minimal melting occurred at the glacier surface during this period of high reflectivity, as indicated by low discharge and high conductivity values recorded at the proglacial stream (Fig. 3). Because there was little storage or delay of water as it moved through the drainage system, surface-energy conditions controled the magnitude and timing of englacial flow. The energy balance observed during the ablation season under generally clear skies on Conness Glacier is probably typical of highaltitude glaciers dominated by cool, dry air masses in the middle latitudes. Ablation is likely to be controled by net radiation due to relatively high incoming solar radiation and the lower air temperatures and vapor pressures typical of their high-altitude location (Röthlisberger and Lang, 1987, p. 220).

\section{CONCLUSION}

Analysis of the electrical conductivity of glacial meltwater suggests that flow separation using a simple mass-balance model is a useful technique in small alpine glaciers with relatively low solute concentrations. Diurnal hydrographs for total flow are symmetrical because run-off was

Table 2. Regression equations

\begin{tabular}{|c|c|c|c|c|c|c|c|c|c|}
\hline \multirow[t]{2}{*}{ Equation } & \multirow[t]{2}{*}{$\mathcal{N}$} & \multirow{2}{*}{$\begin{array}{l}\text { Prob. } \\
\text { level }\end{array}$} & \multirow[t]{2}{*}{$R^{2}$} & \multirow{2}{*}{$\begin{array}{l}\text { Durbin- } \\
\text { Watson }\end{array}$} & \multicolumn{5}{|c|}{ Residual autocorrelation at lag } \\
\hline & & & & & 1 & 2 & 3 & 4 & 5 \\
\hline$Q_{\mathrm{t}}=13.34+0.07 Q_{\mathrm{NR}}$ & 121 & 0.001 & 0.67 & 0.59 & 0.67 & 0.44 & 0.23 & 0.04 & -0.07 \\
\hline$Q_{\mathrm{t}}=10.13+0.08 Q_{\mathrm{NR}-1}$ & 121 & 0.001 & 0.86 & 1.00 & 0.42 & 0.17 & 0.14 & 0.28 & 0.31 \\
\hline$Q_{\mathrm{s}}=2.15+0.01 Q_{\mathrm{NR}}$ & 121 & 0.006 & 0.06 & 2.07 & -0.04 & -0.03 & -0.03 & 0.00 & 0.01 \\
\hline$Q_{\mathrm{s}}=2.43+0.01 Q_{\mathrm{NR}+1}$ & 120 & 0.004 & 0.07 & 2.09 & -0.04 & -0.04 & -0.01 & 0.00 & 0.03 \\
\hline$Q_{\mathrm{e}}=11.21+0.06 Q_{\mathrm{NR}}$ & 121 & 0.001 & 0.54 & 1.10 & 0.43 & 0.28 & 0.07 & -0.08 & -0.12 \\
\hline$Q_{\mathrm{e}}=7.65+0.05 Q_{\mathrm{NR}-1}$ & 121 & 0.001 & 0.70 & 1.66 & 0.15 & 0.00 & 0.00 & 0.06 & 0.06 \\
\hline
\end{tabular}

" Note that $Q_{\mathrm{NR}+1}$ is $Q_{\mathrm{NR}}$ at time $t+1$, as indicated by the negative lag in the cross-correlation analysis in Table 1 . 
dominated by ablation-derived englacial flow which was transmitted rapidly through the hydrologic system. Electrical conductivity varied inversely with discharge, and exhibited an abrupt increase at the conductivity maxima. Cross-correlation analysis indicated that subglacial discharge peaked on the rising limb of the englacial cycle, about $2 \mathrm{~h}$ before the englacial peak. These results suggest that increased water pressure in the englacial system generated by surface melting forced longer residence-time subglacial water from beneath the glacier in advance of the englacial flow. Solute-rich subglacial water was routed to the surface in the lower part of the glacier to flow in two main supraglacial stream channels which continued to flow through the night.

Proglacial discharge responded quickly to variations in net radiation, which was by far the most important component of the energy balance. Net radiation (lagged $-1 \mathrm{~h}$ ) explained $86 \%$ of the variance in proglacial discharge through its control of englacial flow. A brief snowfall event decreased net radiation by reducing incoming shortwave radiation and increasing surface albedo. This produced an immediate hydrologic response whereby proglacial discharge decreased and conductivity increased dramatically.

\section{ACKNOWLEDGEMENTS}

This research was conducted as part of a joint effort in cooperation with F. Chambers, S. Lamm and T. Miller to investigate the microclimatology, mass balance and hydrology of Conness Glacier. J. Knox and R. Pavlowsky helped in the revision of an early draft of the manuscript. A. Gurnell and an anonymous reviewer made many helpful criticisms of a later version of the manuscript. J. Lecce and $M$. Lecce assisted in the preparation and modification of the field equipment.

\section{REFERENCES}

Bateman, P. C., R. W. Kistler, D. L. Peck and A. Busacca. 1983. Geologic map of the Tuolumne Meadows quadrangle, Yosemite National Park, California. U.S. Geol. Surv. Geol. Quadrangle Map GQ-1570.

Brown, M.J. 1986. Use of stream chemistry to estimate hydrologic parameters. Water Resour. Res., 22(5), 805811.

Caine, N. 1989. Hydrograph separation in a small alpine basin based on inorganic solute concentrations. $\mathcal{J}$. Hydrol., 112(1-2), 89-101.

Chambers, F.B. 1990. Cold air ponding and cirque glaciation: Conness Glacier, California. Association of American Geographers. Program and Abstracts, 34.

Collins, D. N. 1978. Hydrology of an Alpine glacier as indicated by the chemical composition of meltwater. $Z$. Gletscherkd. Glazialgeol., 13(1/2), 1977, 219-238.

Collins, D. N. 1979a. Hydrochemistry of meltwaters draining from an Alpine glacier. Arct. Alp. Res., $11(3), 307-324$.

Collins, D. N. 1979b. Quantitative determination of the subglacial hydrology of two Alpine glaciers. F. Glaciol., 23(89), 347-362.

Fenn, C.R. 1987. Electrical conductivity. In Gurnell, A. M. and M.J. Clark, eds. Glacio-fluvial sediment transfer; an alpine perspective. Chichester, etc., John Wiley and Sons, 377-414.

Gurnell, A. M. and C.R. Fenn. 1984. Flow separation, sediment source areas and suspended sediment transport in a pro-glacial stream. Catena Supplement 5, 109119.

Gurnell, A. M. and C.R. Fenn. 1985. Spatial and temporal variations in electrical conductivity in a pro-glacial stream system. F. Glaciol., 31(108), 108114.

Hooper, R. P. and C. A. Shoemaker. 1986. A comparison of chemical and isotopic hydrograph separation. Water Resour. Res., 22(10), 1444-1454.

Male, D.H. and D. M. Gray. 1981. Snowcover ablation and runoff. In Gray, D. M. and D.H. Male, eds. Handbook of snow; principles, processes, management and use. Toronto, etc., Pergamon Press, 360-436.

Marcus, M.G., R.D. Moore and I. F. Owens. 1985. Short-term estimates of surface energy transfers and ablation on the lower Franz Josef Glacier, South Westland, New Zealand. N.Z. J. Geol. Geophys., 28(3), 559-567.

Oerter, H., H. Behrens, G. Hibsch, W. Rauert and W. Stichler. 1980. Combined environmental isotope and electrical conductivity investigations of the runoff of Vernagtferner (Oetztal Alps). Mater. Glyatsiol. Issled. Khron. Obsuzhdeniya 39, 157-161.

Pinder, G. F. and J. F. Jones. 1969. Determination of the ground-water component of peak discharge from the chemistry of total runoff. Water Resour. Res., 5(2), 438445.

Rainwater, F. H. and H. P. Guy. 1961. Some observations on the hydrochemistry and sedimentation of the Chamberlain Glacier area, Alaska. U.S. Geol. Surv. Prof. Pap. 414-C.

Röthlisberger, H. 1972. Water pressure in intra- and subglacial channels. F. Glaciol., 11(62), 177-203.

Röthlisberger, H. and H. Lang. 1987. Glacial hydrology. In Gurnell, A. M. and M.J. Clark, eds. Glacio-fluvial sediment transfer; an alpine perspective. Chichester, etc., John Wiley and Sons, 207-284.

Shreve, R. L. 1972. Movement of water in glaciers. 7 . Glaciol., 11(62), 205-214.

Wendler, G. and G. Weller. 1974. A heat-balance study on McCall Glacier, Brooks Range, Alaska: a contribution to the International Hydrological Decade. 7 . Glaciol., 13(67), 13-26.

The accuracy of references in the text and in this list is the responsibility of the author, to whom queries should be addressed. 